\title{
Variation of Indigofera tinctoria's Immersion Time on Dye Solution and its effect on DSSC efficiency
}

\author{
Fahru Nurosyid“, Parahita Faqih, Zulaldi Yahya Dewangga, and Nurdiyantoro \\ Putra Prasetya
}

Physics Department, Faculty of Mathematics and Natural Sciences, Universitas Sebelas Maret, Surakarta

*fahrunurosyid@staff.uns.ac.id

\section{ABSTRACT}

The utilization of Indigo tinctoria as a DSSC sensitizer has been done to study the effect of I. tinctoria's immersion time on DSSC efficiency. One of the most essential components in DSSC is a sensitizer or dye. In this work, the dye has been used in DSSC is the natural indigo dye from I. tinctoria leaves. The extraction was done by dissolving 50 grams of I. tinctoria leaves in 500 mililiters aquades and soaking in various time: $12,24,36$, and 48 hours. The optical properties of dye solution was characterized by UVVis spectrophotometer and the current-voltage of DSSC was characterized by Keithley I-V Meter. The highest absorbance is 2.7 of $48 \mathrm{~h}$ dye solution, but the best efficiency of DSSC is $5.39 \times 10^{-3} \%$ that owned 24 h cell.

Keywords: DSSC, Indigofera tinctoria.

\section{INTRODUCTION}

One of the renewable energies in the world is solar energy. Dye Sensitized Solar Cell (DSSC) is a device that can convert light energy into electrical energy with photosensitizer based ${ }^{[1-3]}$. The advantages of DSSC are economical, simple to fabricate, easily obtained the materials, and have excellent conversion efficiencies ${ }^{[4]}$. DSSC is composed of three main components namely working electrode, counter electrode and electrolyte solution ${ }^{[5,6]}$. The working electrode is composed of transparent conductive glass, such as Fluorine-doped Tin Oxide (FTO), $\mathrm{TiO}_{2}$ nanocrystalline semiconductor layer and dye active layer. Dye serves as a sensitizer in which the transfer of electrons to the $\mathrm{TiO}_{2}$ semiconductor occurs. Dyes are basically divided into two kinds: organic dyes and synthetic dyes. Organic dyes or natural dyes are dyes that are ingredients derived from nature, whereas synthetic dyes are dyes that material derived from chemical compounds. Natural dyes unlimited availability, environmentally friendly, cheap and the process of making it very simple. While the synthetic dyes are very limited, can cause environmental pollution, using some expensive metals and complicated manufacturing processes ${ }^{[7,8]}$.

In this study, indigo pigment was used as a sensitizer from Indigo tinctoria leaves. The indigo plant (Indigofera sp.), which is one of the oldest natural dye in the world and has been used since the ancient periods. This plant has many species, but the most commonly species are $I$. arrecta and I. tinctoria ${ }^{[9]}$. I. tinctoria is widespread across tropical regions around the world. The plant has been cultivated and highly valued for centuries as a main source of indigo dye. Commonly called as 'true indigo', I. tinctoria is a primary source of natural dye among the indigo plants as shown in Figure 1. 


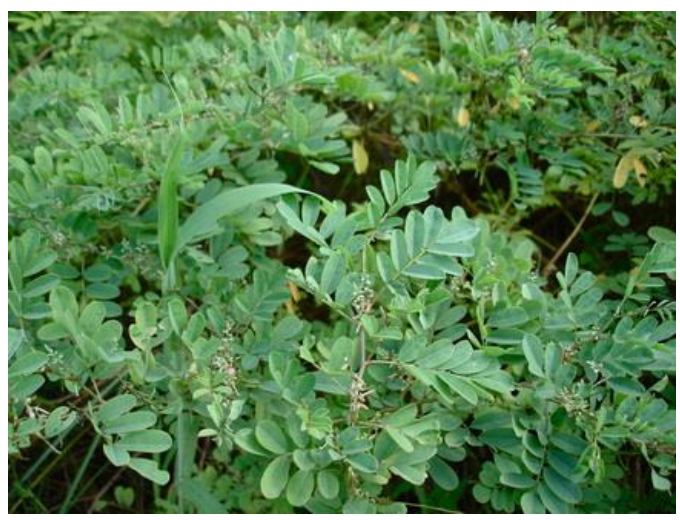

Figure 1. Organic Dye Indigofera tinctoria (Private document)

Indigo blue colour comes from indican substances contained in Indigofera leaves. After soaking the leaves in water, hydrolysis reaction will bring indoxyl (white colour) and glucose. The indoxyl is transformed into blue colour after aeration is performed. If the fabric is dipped in a mixture of fermentation solution containing indoxyl and dried in the fresh air, it will generate insoluble indigo and change into blue colour. Indigo precipitates in the form of cis isomerization and turns into trans isomer that will change into blue color ${ }^{[10]}$. Indigo is a group of carbonyl compound and one of the oldest known dyes in terms of natural dyes. According to a derivative of a group of organic compounds that are colourless glucoside from a form of "enol" from an indoxyl, for example indican. Indigo is formed from indican because the fermentation process of Indigofera species plant is followed by oxidation by free air of indoxyl ${ }^{[11-13]}$. Figure 2 shows the reaction illustrates the extraction of indigo colour.

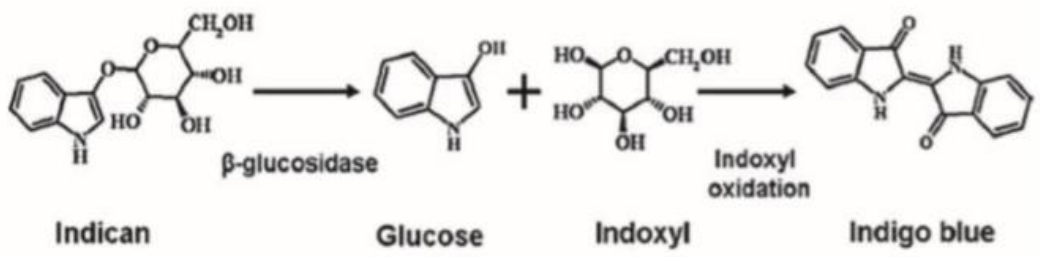

Figure 2. Reaction to produce natural dye indigo ${ }^{[14]}$.

\section{METHOD}

DSSC structure was used in this research is sandwich structure, that consists of working electrode, counter electrode, dye as photosensitizer, and electrolyte as redox mediators. The extraction dye was done by cut and take the leaves of I. tinctoria (better before sunrise). 50 grams I. tinctoria leaves are dissolved in 500 mililiters aquades. We make sure all the leaves are soaked; and they're soaked in various time: $12,24,36$, and 48 hours. The FTO glass ( 2 $\mathrm{cm} \times 2 \mathrm{~cm}$ ) was washed by aquades, acetone, and alcohols every 10 minutes, respectively, using the ultrasonic bath. The $\mathrm{TiO}_{2}$ paste is made from 3 grams of transparent $\mathrm{TiO}_{2}$ with 3 $\mathrm{ml}$ of ethanol and they're stirred using a magnetic stirrer for \pm 4 hours at $300 \mathrm{rpm}$ so that both materials become homogeneous solutions. $\mathrm{The}^{\mathrm{TiO}} 2$ paste deposition on the substrat by using a spin coating method with a rotation speed of $1000 \mathrm{rpm}$ for 1 minute. Then $\mathrm{TiO}_{2}$ is annealed using furnace with temperature of $550^{\circ} \mathrm{C}$ for 60 minutes with heating rates 15 . After that, the working electrode is soaked in dye solution for 24 hours. For the counter electrode used platinum dissolved in ethanol. The platinum solution is applied to a FTO glass over a hot plate of $250^{\circ} \mathrm{C}$ by brush method. The scotch tape is used on the FTO glass to avoid contact between the working electrode and the counter electrode. Electrolyte is applied to the counter electrode. Working electrodes and counter electrodes are combined using a binder clip. 
The absorption spectra of indigo dye solutions were recorded using a $U V$-Visible spectrophotometer Lambda 25. The absorption analysis was conducted in the wavelength range from 400 to $800 \mathrm{~nm}$. The $I-V$ characteristic curves under simulated sunlight $1000 \mathrm{~W} / \mathrm{m}^{2}$ were conducted using Keithley $I-V$ meter. Based on $I-V$ curve, the fill factor $(F F)$ can be calculated as:

$$
F F=\frac{I_{m} V_{m}}{I_{S C} V_{O C}}
$$

where $\mathrm{Im}$ and $\mathrm{Vm}$ are the photocurrent and photovoltage for maximum power output $(\mathrm{Pm})$, $I S C$ and $V O C$ are the short-circuit photocurrent and open-circuit photovoltage, respectively. The overall energy conversion efficiency $(\eta)$ is defined as

$$
\eta=\frac{F F I_{S C} V_{O C}}{P_{\text {in }}} \times 100 \%
$$

where Pin is the power of incident light.

\section{RESULT AND DISCUSSION}

\section{Absorption Spectra of Dye Solutions with Immersion Time Variation}

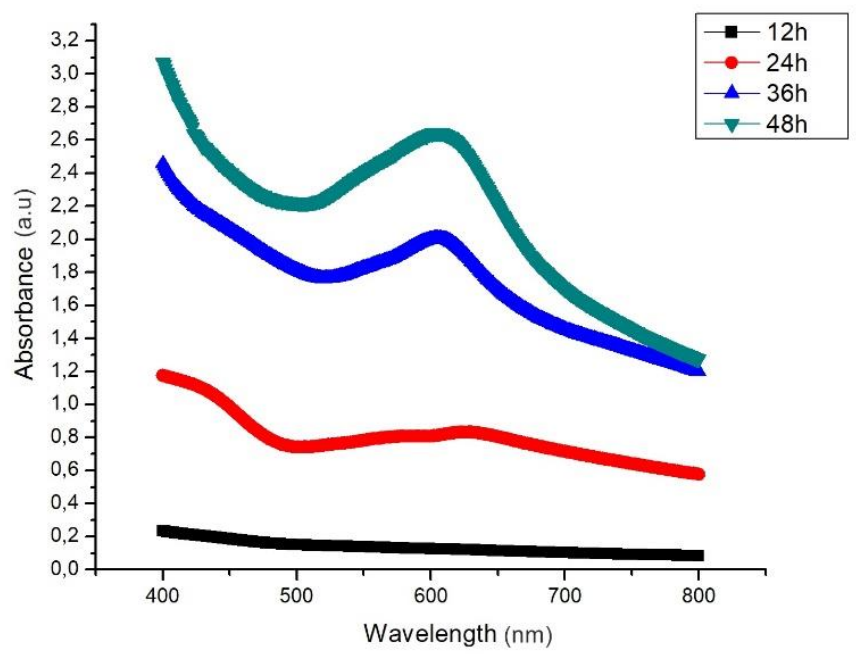

Figure 3. Absorption spectra of indigo dye

Figure 3 shows that the absorbance peak of the indigo dye solution occurs at a wavelength of $600 \mathrm{~nm}$. The highest absorbance is 2.7 of $48 \mathrm{~h}$ solution. The wave peak occurs from dye $36 \mathrm{~h}$ solution. The dye solution with immersion time for 12 hours (12h) shows only straight line because the solution is still clear and the leaves have not been perfectly fermented. Clear solutions show a low absorbance rate because more light is transmitted so that no absorbance peak occurs. The longer the immersion time so the solution color is getting older, so that the absorbance is higher. The highest absorbance is owned 48 hours (48h) immersion time of dye solution.

\section{I-V Characterization}

Characterization of Current and Voltage is done using Keithley I-V meter. The measured DSSC performance can be seen in Table 1. 
Table 1. $I-V$ Characteristics of DSSC

\begin{tabular}{cccccc}
\hline Sample & $\operatorname{Imax}(A)$ & $\operatorname{Vmax}(\mathbf{V})$ & $\boldsymbol{P} \max (\mathbf{W})$ & $\boldsymbol{P i n}(\mathbf{W})$ & Efficiency (\%) \\
\hline 12 h Cell & $5,60 \times 10^{-6}$ & 0,03 & $1,70 \times 10^{-7}$ & 0,05 & $3,40 \times 10^{-4}$ \\
24 h Cell & $2,54 \times 10^{-5}$ & 0,10 & $2,69 \times 10^{-6}$ & 0,05 & $5,39 \times 10^{-3}$ \\
36 h Cell & $9,40 \times 10^{-6}$ & 0,12 & $1,14 \times 10^{-6}$ & 0,05 & $2,28 \times 10^{-3}$ \\
48 h Cell & $8,10 \times 10^{-6}$ & 0,08 & $7,29 \times 10^{-7}$ & 0,05 & $1,46 \times 10^{-3}$ \\
\hline
\end{tabular}



Figure 4. $I-V$ Curve of DSSC

Figure 4 is a graph of $I-V$ characterization showing different voltage and current outputs due to immersion time. The efficiency of $36 \mathrm{~h}$ and $48 \mathrm{~h}$ cells actually decreased so that the greatest efficiency is owned by the $24 \mathrm{~h}$ cell, that is $5.39 \times 10^{-3} \%$. Although the highest absorbance is owned $48 \mathrm{~h}$ solution, but the $24 \mathrm{~h}$ dye solution produces the highest DSSC output when the dye was binding with $\mathrm{TiO}_{2}$. It is possibly due to the fermentation time with an interval of 24 hours shows the condition of bacteria (an aerobic) that achieve optimum condition because of the temperature, time and $\mathrm{pH}$ were met by nutrients.

\section{CONCLUSION}

The highest absorbance of dye solution is 2.7 of $48 \mathrm{~h}$ solution but the best efficiency of DSSC is $5.39 \times 10^{-3} \%$ that owned $24 \mathrm{~h}$ cell. It is possibly due to the fermentation time with an interval of 24 hours shows the condition of bacteria (an aerobic) that achieve optimum condition.

\section{REFERENCES}

1 Grätzel, M. 2005. Solar Energy Conversion by Dye Sensitized Photovoltaic Cells. Journal of Inorganic Chemistry, Vol. 44, No. 20, Hal. 6841-6851.

2 Kibria, M. T., Ahammed, A., Sony, S. M., Hossain, F., \& Islam, S. U. 2014. A Review: Comparative Studies on Different Generation Solar Cells Technology. Proc. of 5th International Conference on Environmental Aspects of Bangladesh.

3 Dodoo-Arhin, D., Howe, R.C.T., Hu, G., Zhang, Y., Hiralal, P., Bello, A., Amaratunga, G., \& Hasan, T. 2016. Inkjet-printed Graphene Electrodes for Dye-Sensitized Solar Cells. Carbon, Vol. 105, Hal. 33-41. 
4 Maurya, I. C., Srivastava, P., \& Bahadur, L. 2016. Dye-Sensitized Solar Cell Using Extract from Petals of Male Flowers Luffa Cylindrica L. as a Natural Sensitizer. Optical Materials, Vol. 52, Hal. 150-156.

5 Sharma, S., Jain, K. K., \& Sharma, A. 2015. Solar cells: in research and applications-a review. Materials Sciences and Applications, Vol. 6, No. 12, Hal. 1145.

6 Yun, S., Lund, P.D., \& Hinsch, A. 2015. Stability assessment of alternative platinum free counter electrodes for dye-sensitized solar cells. Energy Environ Sci, Vol. 8, No. 12, Hal. 3495-514.

7 Lim, A., Kumara, N.T.R.N., Tan, A.L., Mirza, A.H., Chandrakanthi, R.L.N., Petra, M.I., Ming, L.C., Senadeera, G.K.R., \& Ekanayake, P. 2015. Potential natural sensitizers extracted from the skin of Canarium odontophyllum fruits for dye-sensitized solar cells. Spectrochim. Acta, Part A, Vol. 138, Hal. 596-602.

8 Chang, H., Wu, H.M., Chen, T.L., Huang, K.D., Jwo, C.S., \& Lo, Y.J. 2010. Dyesensitized solar cell using natural dyes extracted from spinach and ipomoea. Alloys Compd, Vol. 495, Hal. 606-610.

9 Nurmavianti, S. 2014. Analisis Nilai Tambah Pemanfaatan Indigofera sebagai Bahan Pewarna Alami Batik Tulis di Kecamatan Imogiri Kabupaten Bantul. Skipsi. Program Studi Agribisnis Jurusan Sosial Ekonomi Pertanian Fakultas Pertanian Universitas Gadjah Mada. Yogyakarta.

10 Handayani, P. A. \& Mualimin, A. A. 2009. Pewarna Alami Batik dari Tanaman Nila (Indigofera) dengan Katalis Asam. Jurnal Bahan Alam Terbarukan. ISSN 2303-0623. Prodi Teknik Kimia Fakultas Teknik Universitas Negeri Semarang.

11 Chanayath, N., Lhieochaiphant, S., \& Phutrakul, S. 2002. Pigment Extraction Techniques from the Leaves of Indigofera tinctoria Linn. and Baphicacanthus cusia Brem. and Chemical Structure Analysis of Their Major Components. CMU Journal. Vol. 1, Hal. 149-160.

12 Tayade, P.B., \& Adivarekar, R. V. 2014. Extraction of Indigo Dye from Couroupita Guianensis and its Application on Cotton Fabric. Fashion and Textiles Journal, Hal. 116.

13 Adalina, Y., Luciasih, A., \& Andi, R. 2010. Sumber Bahan Pewarna Alami sebagai Tinta Sidik Jari Pemilu. Pusat Penelitian dan Pengembangan Hutan dan Konservasi Alam. Badan Penelitian dan Pengembangan Kehutanan Departemen Kehutanan. Bogor.

14 Kim, J. Y., Lee, J. Y., Shin, Y. S., \& Kim, G. J. 2009. Mining and Identification of a Glucosidase Family Enzyme with High Activity toward the Plant Extract Indican. Journal of Molecular Catalysis B: Enzymatic. Vol. 57, Hal. 284-291. 